C-suite is tasked with financial solvency, they should recognize a diverse workforce boosts the bottom line. Ultimately financial return may be the motivating factor but the true value is the human return.

\footnotetext{
References

1. Ortmeyer KA, Raman V, Tiko-Okoye C, Espinosa J, Cooke DT, Erkmen C. Women and minorities underrepresented in academic cardiothoracic surgery: it's time for next steps. Ann Thorac Surg. November 5, 2020 [Epub ahead of print].

2. Ceppa DP, Ikonomidis JS, Timsina LR, Boden N, Kane LC, Donington JS. STS 2019 workforce report: ad hoc analysis of women in cardiothoracic surgery. Ann Thorac Surg. October 15, 2020 [Epub ahead of print].

3. Backhus LM, Fann BE, Hui DS, Cooke DT, Berfield KS, Moffatt-Bruce SD. Culture of safety and gender inclusion in cardiothoracic surgery. Ann Thorac Surg. 2018;106:951-8.
}

4. Ortmeyer KA, Raman V, Tiko-Okoye C, Espinosa J, Cooke DT, Starnes SL, et al. Goals, organizational change, advocacy, diversity literacy, and sustainability: a checklist for diversity in cardiothoracic surgery training programs. J Thorac Cardiovasc Surg. 2021;162:1782-7.

5. Sola O, Kothari P, Mason HRC, Onumah CM, Sánchez JP. The crossroads of health policy and academic medicine: an early introduction to health policy skills to facilitate change. MedEdPORTAL. 2019;15:10827.

6. Gomez LE, Bernet P. Diversity improves performance and outcomes. J Natl Med Assoc. 2019;111:383-92.

7. pwc. Increasing diversity in the legal ranks. Available at: https://www.pwc.com/ us/en/services/assets/pwc-increasing-diversity-in-the-legal-ranks.pdf. Accessed December 12, 2020.

8. CEO Action. How are $\mathrm{CEO}$ Action signatories collaborating to advance racial equity?. Available at: https://www.ceoaction.com/. Accessed December 13, 2020.

9. Kibbe MR, Freischlag J. Call to action to all surgery journal editors for diversity in the editorial and peer review process. JAMA Surg. 2020;155:1015-6.

10. Carnethon MR, Kershaw KN, Kandula NR. Disparities research, disparities researchers, and health equity. JAMA. 2020;323:211-2.
See Article page 1782.

\section{Commentary: We need diversity in cardiothoracic surgery}

\author{
Ikenna Okereke, MD
}

There have been many appalling events this year that highlight the inequities faced by underrepresented communities. Many surgical specialties have struggled with a lack of diversity. Only 5\% of general surgeons are African American, ${ }^{1}$ and as of 2017, there were only 6 female African American cardiothoracic surgeons practicing in the United States. ${ }^{2}$ In their article in this issue of the Journal, Ortmeyer and colleagues ${ }^{3}$ discuss strategies to improve the level of diversity in cardiothoracic programs. More diversity would bring such benefits as increased creativity and better ability to relate to a wider percentage of the population. ${ }^{4}$

Many institutions have created committees dedicated to improving diversity, equity, and inclusion in response to

\footnotetext{
From the Division of Cardiothoracic Surgery, University of Texas Medical Branch, Galveston, Tex.

Disclosures: The author reported no conflicts of interest.

The Journal policy requires editors and reviewers to disclose conflicts of interest and to decline handling or reviewing manuscripts for which they may have a conflict of interest. The editors and reviewers of this article have no conflicts of interest.

Received for publication Nov 19, 2020; revisions received Nov 19, 2020; accepted for publication Nov 19, 2020; available ahead of print Nov 28, 2020.

Address for reprints: Ikenna Okereke, MD, Division of Cardiovascular and Thoracic Surgery, Department of Surgery, University of Texas Medical Branch, 301 University Blvd, Galveston, TX 77555 (E-mail: ikokerek@utmb.edu).

J Thorac Cardiovasc Surg 2021;162:1789-90

$0022-5223 / \$ 36.00$

Copyright (C) 2020 by The American Association for Thoracic Surgery

https://doi.org/10.1016/j.jtcvs.2020.11.094
}

Check for updates

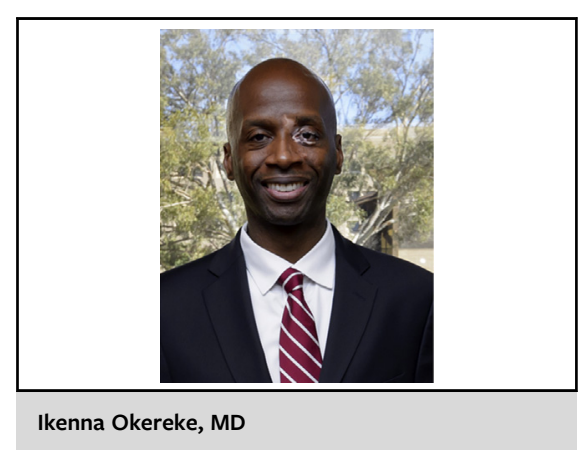

CENTRAL MESSAGE

Diversity in workforce increases creativity and broadens the community served. Specific goals and projects will improve the chance of increasing diversity in cardiothoracic surgery.

national tragedies. Unfortunately, however, most diversity efforts do not succeed. ${ }^{5}$ Strategies with noble intentions, such as mandatory diversity training, actually have been associated with a decreased level of diversity. ${ }^{6}$ When evaluating the function of these diversity committees, there is one glaring observation: there is no standard among them.

The GOALS checklist presented by Ortmeyer and colleagues attempts to address this lack of consistency by creating a set of guidelines for institutions. The authors have created a useful starting point. Using their checklist 
with specific metrics should result in more diversity, but it will be important for each institution to have unambiguous objectives. In the short term, each cardiothoracic program should pick a specific area in which diversity is lacking and formulate a plan to address that problem. For example, if the goal is to increase the number of underrepresented attending surgeons in the program, then the entire hiring process should be studied. The job announcement should emphasize the desire to make the program more diverse, as many job seekers will be attracted to a program that is seeking a more diverse workforce. The search committee should be encouraged to include underrepresented staff as members. If there are no underrepresented surgeons in that cardiothoracic program, a surgeon from another division or department should be included if possible. Some of these measures are simple but can be relatively effective.

In addition to these short-term measures, each institution should consider strategies to increase the number of underrepresented candidates. The "leaky pipeline" phenomenon refers to the gradual withdrawal over time of underrepresented students from many professional careers owing to a lack of support, unavailability of role models, and increased financial hardships. ${ }^{7}$ To address this phenomenon, our cardiothoracic division instituted an outreach program at a local high school with a predominantly underrepresented student body. On Saturday mornings, we perform basic surgical tasks with the students in our surgical simulation lab, then take the students on a tour of the hospital and medical school. A survey administered before and after the program has shown increased interest among the participants in becoming a surgeon and more confidence in being able to accomplish career goals on the repeat survey.

There is a continuing need to increase diversity in cardiothoracic programs. Having specific goals, using short-term strategies, and initiating long-term activities will reduce the disparities in the future.

\section{References}

1. Association of American Medical Colleges. Diversity facts and figures; January 1, 2017. Available at: http://www.aamcdiversityfactsandfigures.org/. Accessed June $13,2020$.

2. Neumann J. "Black Women in Medicine" relays struggles, triumphs of doctors. Chicago Tribune; February 6, 2017. Available at: https://www.chicagotribune. com/entertainment/tv/ct-black-women-med-tv-ent-0207-20170206-story.html. Accessed November 12, 2020.

3. Ortmeyer KA, Raman V, Tiko-Okoye C, Espinosa J, Cooke DT, Starnes SL, et al. Goals, organizational change, advocacy, diversity literacy, and sustainability: a checklist for diversity in cardiothoracic surgery training programs. J Thorac Cardiovasc Surg. 2021;162:1782-7.

4. Cohen JJ, Gabriel BA, Terrell C. The case for diversity in the health care workforce. Health Aff (Millwood). 2002;21:90-102.

5. Poole KG Jr, Jordan BL, Bostwick JM. Mission drift: are medical school admissions committees missing the mark on diversity? Acad Med. 2020;95:357-60.

6. Dobbin F, Kalev A. Why diversity programs fail. Harvard Business Review; JulyAugust 2016. Available at: https://hbr.org/2016/07/why-diversity-programs-fail. Accessed December 16, 2020

7. Upshur CC, Wrighting DM, Bacigalupe G, Becker J, Hayman L, Lewis B, et al. The healthy equity scholars program: innovation in the leaky pipeline. J Racial Ethn Health Disparities. 2018;5:342-50.

8. Mohan N, Hughes BD, Williams TP, Perez AG, Tyler DS, Okereke IC. Use of surgical simulation by underrepresented high school students to address diversity gaps in surgery. Ann Surg Open. 2020;1:e013. 